\title{
Het MAB gaat Open Access!
}

Philip Wallage

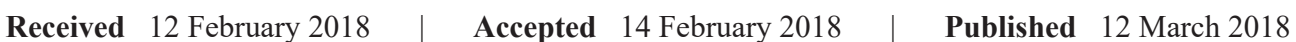

Het MAB verscheen voor het eerst in januari 1924 en publiceert sindsdien bijdragen op het terrein van accountancy en bedrijfseconomie, gericht op het toepassen van wetenschappelijke kennis in de praktijk. Het is het enige Nederlandse wetenschappelijke tijdschrift op genoemde vakgebieden.

Op dit moment wordt het blad gelezen door ruim 600 abonnees en 3.000 studenten verbonden aan een van de Nederlandse post-Master-accountantsopleidingen.

Maar tijden veranderen en zo ook het MAB. De kernredactie heeft besloten het blad met ingang van 2018 in Open Access uit te geven. Wetenschappelijke publicaties op het terrein van accountancy en bedrijfseconomie komen zodoende voor iedereen digitaal en in gratis vorm beschikbaar. Ook jonge onderzoekers krijgen hiermee een platform om hun onderzoek voor een breed publiek toegankelijk te maken.

Juist nu wetenschap een onmisbare maatschappelijke rol vervult is maatschappelijke valorisatie van wetenschappelijk onderzoek van groot belang. De overgang naar Open Access past in de breed gedragen initiatieven die in Europa en in Nederland zijn gestart en worden ge- steund door het ministerie van OCW, VSNU, universiteiten, hogescholen en bibliotheken.

Wij zijn heel blij dat de Nederlandse post-Master-accountancyopleidingen en een aantal accountantskantoren en instellingen zich reeds bereid heeft verklaard om financieel bij te dragen aan het publiceren in Open Access.

Met de introductie van Open Access is onze website www.mab-online.nl geheel vernieuwd.

Wij hopen van harte dat $\mathrm{u}$ als trouwe lezer van het MAB ook wilt bijdragen. Dit kunt $u$ doen door het blad in printvorm te blijven ontvangen. Wij bieden u dit partnership aan voor $€ 90$ euro incl. btw per jaar. U ontvangt dan, zoals u gewend bent, 6 nummers, zwart/wit binnenwerk en cover in kleur.

Via onze website kunt $\mathrm{u}$ zich hiervoor opgeven.

Evenals de afgelopen 94 jaar hopen wij ook in de toekomst de totstandkoming en verspreiding van (wetenschappelijke) kennis op het terrein van accountancy en bedrijfseconomie voor een brede lezersgroep te faciliteren!

Namens de redactie, Philip Wallage (voorzitter) 